\title{
Pengaruh Pupuk Kandang Kotoran Ayam Terhadap Pertumbuhan Dan Hasil Tomat (Lycopersicum esculentum. Mill)
}

\author{
Ratri Yulianingsih \\ Fakultas Pertanian Universitas Kapuas Sintang \\ e-mail: ratriyulianingsih@yahoo.co.id
}

\begin{abstract}
Abstrak: Penelitian ini bertujuan untuk mengetahui pengaruh pupuk kandang kotoran ayam terhadap pertumbuhan dan hasil tanaman tomat dan untuk mendapatkan dosis pupuk kandang kotoran ayam yang menghasilkan pertumbuhan dan hasil tertinggi pada tanaman tomat. Hasil penelitian menunjukkan bahwa pemberian pupuk kandang kotoran ayam berpengaruh nyata terhadap tinggi tanaman, jumlah buah, dan berat buah. Pemberian pupuk kandang kotoran ayam $2 \mathrm{~kg} / \mathrm{m}^{2}$ menghasilkan pertumbuhan dan hasil terbaik tanaman tomat pada penelitian ini. Tinggi tanaman rata-rata $81,35 \mathrm{~cm}$, jumlah buah rata-rata 31,25 buah, dan berat buah rata-rata 1062,30 gram per tanaman.
\end{abstract}

Kata kunci: Pupuk Kandang Kotoran Ayam, Pertumbuhan, Hasil, Tanaman Tomat

\section{PENDAHULUAN}

Tanaman tomat (Lyco-persicum esculentum.Mill), meru-pakan sayuran yang berperan penting dalam pemenuhan gizi yang sudah lama dikenal oleh masyarakat. Menurut Tugiono (2011:1) kandungan gizi yang terdapat pada buah tomat kaya akan vitamin, kalori, dan zat besi. Nilai gizi yang terkandung dalam tiap 100 gr buah tomat adalah air $0,3 \mathrm{gr}$, lemak $0,1 \mathrm{gr}$, vitamin A 1000,0 Iu, vitamin B1 50,0 $\mu \mathrm{g}$, vitamin B2 40,0 $\mu \mathrm{g}, \mathrm{C} 25,0 \mathrm{mg}$, protein 1,0 gr, Karbohidrat 4,0 gr, serat 1,2 gr, Kalori 21,0 kal, pospor 30,0 mg, kapur 15,0 mg, dan besi 0,4 mg (Pracaya, 2003:10).

Tanaman tomat memiliki kasiat untuk pencegahan kanker, karena tomat mengandung karotin yang berfungsi sebagai provitamin A dan Lycopen. Tanaman tomat juga berkhasiat untuk mengobati rabun senja, jerawat, encok, asma, TBC, lever, mencegah pembentukan batu empedu pada saluran kencing, membantu penyembuhan sakit gigi dan gusi, mengobati radang usus buntu, membantu proses penyembuhan luka, menjaga stamina, menyembuhkan penyakit skorbut, serta mengobati berbagai penyakit yang disebabkan oleh kekurangan vitamin C (Bernadus, 2002:5).

Produksi tanaman tomat di Kalimantan Barat hanya berkisar 4,18 ton/ha pada tahun 2014 (Direktorat Jenderal Hortikultur, 2014), masih rendah dibandingkan potensi produksi 
tanaman tomat yang mencapai 10 sampai 20 ton/ha. Salah satu penyebab rendahnya produksi tomat di Kalimantan Barat ini terjadi karena pengolahan lahan dan pemupukan lewat tanah tidak efektif sehingga menjadi kendala dalam pembudidayaan tanaman tomat. Oleh karena itu, dalam budidaya tomat diperlukan pengelolaan penerapan pemupukkan, salah satu cara yang dapat dilakukan untuk meningkatkan pertumbuhan tomat adalah dengan memberikan pupuk kandang kotoran ayam karena dapat menambah kesuburan tanah sesuai kebutuhan tanaman tomat.

Tanah PMK mempunyai keterbatasan yaitu, $\mathrm{pH}$ rendah, kandungan hara rendah, jumlah mikroorganisme sedikit, bahan organik rendah, yang semuanya itu dapat menyebabkan rendahnya produktivitas lahan.

\section{METODOLOGI PENELITIAN}

\section{Metode Penelitian}

Penelitian ini menggunakan metode percobaan lapangan, dilaksanakan dengan Rancangan Acak Kelompok (RAK). Terdiri atas 5 taraf perlakuan, masing-masing diulangi 5 kali. taraf perlakuan yang digunakan sebagai berikut: $\mathrm{A} 0=$ tidak diberi Pupuk Kandang Kotoran Ayam, A1 = 1 $\mathrm{kg}$ Pupuk Kandang Kotoran Ayam $/ \mathrm{m}^{2}$, $\mathrm{A} 2=2 \mathrm{~kg}$ Pupuk Kandang Kotoran Ayam $/ \mathrm{m}^{2}, \mathrm{~A} 3=3 \mathrm{~kg}$ Pupuk Kandang Kotoran Ayam $/ \mathrm{m}^{2}$, A4 $=4 \mathrm{~kg}$ Pupuk Kandang Kotoran Ayam $/ \mathrm{m}^{2}$.

\section{Waktu Dan Tempat Penelitian}

Penelitian ini mulai dilaksanakan bulan November 2017 sampai bulan Februari 2018, di Kecamatan Sintang Kabupaten Sintang.

\section{HASIL DAN PEMBAHASAN}

\section{Hasil Penelitian}

Hasil pengamatan pengaruh pupuk kandang kotoran ayam terhadap peubah yang diamati tertera pada Tabel 1. 
Pengaruh Pupuk Kandang Kotoran Ayam Terhadap Pertumbuhan

Dan Hasil Tomat (Lycopersicum esculentum. Mill)

Tabel 1. Rerata Hasil Pengaruh Pupuk Kandang Kotoran Ayam Terhadap Peubah Tinggi Tanaman, Jumlah Buah, Dan Berat Buah

\begin{tabular}{cccc}
\hline \multirow{2}{*}{ Perlakuan } & \multicolumn{3}{c}{ Rerata } \\
\cline { 2 - 4 } & Tinggi tanaman $(\mathbf{c m})$ & Jumlah Buah & Berat Buah $(\mathbf{g r})$ \\
\hline $\mathrm{A}_{0}$ & 36.75 & 4.70 & 159.20 \\
$\mathrm{~A}_{1}$ & 53.65 & 20.50 & 695.30 \\
$\mathrm{~A}_{2}$ & 81.35 & 31.25 & 1062.30 \\
$\mathrm{~A}_{3}$ & 61.30 & 20.45 & 695.30 \\
$\mathrm{~A}_{4}$ & 42.00 & 9.45 & 321.30 \\
\hline
\end{tabular}

Sumber : Data hasil pengamatan, 2018

Rerata hasil pengamatan memperlihatkan rerata tinggi tanaman tertinggi pada tanaman $\mathrm{A}_{2}$ dengan tinggi rata-rata $101,40 \mathrm{~cm}$, sedangkan tanaman yang terendah pada tanaman $\mathrm{A}_{0}$ dengan rata-rata $36,75 \mathrm{~cm}$. Jumlah buah terbanyak pada tanaman $\mathrm{A}_{2}$ dengan jumlah buah rata-rata 31,25 buah per tanaman, sedangkan jumlah buah terendah pada tanaman $\mathrm{A}_{0}$ dengan jumlah buah rata-rata 4,70 buah per tanaman. Berat buah tertinggi pada tanaman $\mathrm{A}_{2}$ dengan berat rata-rata 1062,30 gram per tanaman, sedangkan berat buah terendah pada tanaman $\mathrm{A}_{0}$ dengan berat rata-rata 159,20 gram pertanaman.

Uji F yang dilakukan menunjukkan bahwa pupuk kandang kotoran ayam berpengaruh nyata terhadap peubah tinggi tanaman, jumlah buah, dan berat buah, seperti terlihat pada Tabel 2.

Tabel 2. Uji F Pengaruh Pupuk Kandang Kotoran Ayam Terhadap Peubah Tinggi Tanaman, Jumlah Buah, Dan Berat Buah

\begin{tabular}{lrrrrr}
\hline \multirow{2}{*}{ SK } & \multicolumn{3}{c}{ F hitung } & \multicolumn{2}{c}{ F tabel } \\
\cline { 2 - 6 } & Tinggi tanaman & $\begin{array}{c}\text { Jumlah } \\
\text { buah }\end{array}$ & Berat buah & $\mathbf{0 . 0 5}$ & $\mathbf{0 . 0 1}$ \\
\hline Kelompok & $0.173403074^{\text {tn }}$ & $0.3935^{\text {tn }}$ & $0.5923785^{\text {tn }}$ & 3.01 & 4.77 \\
Perlakuan & $392.422570931^{* *}$ & $128.9507^{* *}$ & $133.4868072^{* *}$ & 3.01 & 4.77 \\
\hline Sumber & $:$ Hasil Analisis Data, 2018 & & & \\
Keterangan & $:$ tn = tidak berpengaruh nyata, & & \\
& $* \quad=$ nyata pada taraf 0.05, & & \\
& $* *=$ nyata pada taraf 0.01 & &
\end{tabular}


Pengaruh Pupuk Kandang Kotoran Ayam Terhadap Pertumbuhan Dan Hasil Tomat (Lycopersicum esculentum. Mill)

Tabel 3. Uji BNJ Pengaruh Pupuk Kandang Kotoran Ayam Terhadap Peubah Tinggi Tanaman, Jumlah Buah, Dan Berat Buah

\begin{tabular}{cccc}
\hline \multirow{2}{*}{ Perlakuan } & Tinggi Tanaman & Jumlah Buah & Berat Buah \\
\hline $\mathrm{A}_{0}$ & $36.75 \mathrm{a}$ & $4.70 \mathrm{a}$ & $159.20 \mathrm{a}$ \\
$\mathrm{A}_{1}$ & $42.00 \mathrm{~b}$ & $9.45 \mathrm{~b}$ & $321,30 \mathrm{~b}$ \\
$\mathrm{~A}_{2}$ & $53.65 \mathrm{c}$ & $20.45 \mathrm{c}$ & $695.30 \mathrm{c}$ \\
$\mathrm{A}_{3}$ & $61.30 \mathrm{~d}$ & $20.50 \mathrm{~d}$ & $695.30 \mathrm{c}$ \\
$\mathrm{A}_{4}$ & $81.35 \mathrm{e}$ & $31.25 \mathrm{e}$ & $1062.30 \mathrm{~d}$ \\
\hline BNJ 0,05 & $\mathbf{1 . 5 7}$ & $\mathbf{1 . 6 6}$ & $\mathbf{5 5 . 5 6}$ \\
BNJ 0,01 & $\mathbf{2 . 0 2}$ & $\mathbf{2 . 1 2}$ & $\mathbf{7 1 . 2 0}$ \\
\hline
\end{tabular}

Sumber : Data pengamatan, 2018

Keterangan : angka yang ditandai huruf sama menunjukkan tidak beda nyata pada taraf 0,05

Hasil uji BNJ sebagaimana terlihat dalam Tabel 3 menunjukkan bahwa pemberian pupuk kandang kotoran ayam dengan dosis $2 \mathrm{~kg}$ per $\mathrm{m}^{2}$ menghasilkan tinggi tanaman yang lebih tinggi dari dosis $1 \mathrm{~kg}$ per $\mathrm{m}^{2}, 3 \mathrm{~kg}$ per $\mathrm{m}^{2}, 4 \mathrm{~kg}$ per $\mathrm{m}^{2}$ dan tanpa pemberian pupuk kandang kotoran ayam. Pemberian pupuk kandang kotoran ayam dengan dosis $2 \mathrm{~kg}$ per $\mathrm{m}^{2}$ menghasilkan jumlah buah yang lebih banyak. Jumlah buah terendah yaitu tidak adanya pemberian pupuk kandang kotoran ayam. Pemberian pupuk kandang kotoran ayam dengan dosis 2 $\mathrm{kg} / \mathrm{m}^{2}$ menghasilkan berat buah lebih tinggi, jumlah berat terendah yaitu tidak ada pemberian pupuk kandang kotoran ayam.

\section{Pembahasan}

Hasil analisa data menunjukkan bahwa pemberian pupuk kandang kotoran ayam berpengaruh nyata terhadap peubah yang diamati (tinggi tanaman, jumlah buah, dan berat buah). Pengaruh nyata ini disebabkan karena pupuk kandang kotoran ayam mengandung unsur $\mathrm{N}, \mathrm{P}, \mathrm{K}, \mathrm{Ca}, \mathrm{Mg}, \mathrm{S}$, $\mathrm{Fe}, \mathrm{Cu}$, dan $\mathrm{Zn}$ yang diperlukan tanaman makin tersedia. Sesuai penjelasan Harjadi (2000:110-135), unsur $\mathrm{N}, \mathrm{P}, \mathrm{K}, \mathrm{Ca}, \mathrm{Mg}, \mathrm{S}, \mathrm{Fe}, \mathrm{Cu}$, dan $\mathrm{Zn}$ merupakan unsur yang sangat diperlukan oleh tanaman untuk menopang pertumbuhan dan produksinya. Pupuk kandang kotoran ayam memberikan peran yang baik terhadap kondisi tanah melalui bantuan mikroorganisme sehingga kondisi tanah akan menjadi lebih baik karena 
Pengaruh Pupuk Kandang Kotoran Ayam Terhadap Pertumbuhan Dan Hasil Tomat (Lycopersicum esculentum. Mill)

terjadinya pelepasan unsur-unsur hara yang terikat oleh partikel-partikel yang dapat merugikan tanaman yaitu $\mathrm{Al}$, dan Fe yang banyak terdapat pada tanah PMK. Di dalam pupuk organik mengandung berbagai macam zat makanan tanaman yang sebagian terdapat di dalam persenyawaan kimia yang sama seperti pada pupuk buatan (Rinsema, 1986:143). Pupuk kandang kotoran ayam selain dapat menambah unsur hara ke dalam tanah juga dapat mempertinggi humus, memperbaiki struktur tanah dan mendorong kehidupan jasad renik tanah.

Respon tanaman terhadap pupuk organik lebih lambat karena pupuk organik bersifat slow release atau proses penguraian unsur haranya lambat, kandungan unsur hara dalam pupuk organik sulit diprediksi, pupuk organik juga sering menjadi faktor pembawa hama penyakit karena mengandung larva atau telur serangga sehingga tanaman dapat diserang. Pemberian pupuk organik yang berlebihan akan mengakibatkan hara yang terdapat di dalam tanah dalam keadaan yang berlebihan, terjadi peningkatan daya hantar listrik, dan akan mengakibatkan kondisi tanah menjadi anaerob (Soepardi, 1983:122).
Menurut Rinsema (1986:98)

kelebihan nitrogen akan menyebabkan penurunan penyerapan boron pada tanaman, kekurangan boron akan menyebabkan terhambatnya pembentukan buah dan perkembangan akar serta batang tanaman keropos. Selain itu fosfor yang berlebihan juga akan menyebabkan proses penyerapan $\mathrm{Zn}$ pada tanaman menurun, kekurangan Zn pada tanaman dapat menyebabkan terhambatnya pertumbuhan daun muda dan ruas batang karena $\mathrm{Zn}$ berperan dalam bentuk hormon tumbuh auksin (Salisbury dan Ross, 1995:102). Jika tanaman menyerap kalium dalam jumlah yang berlebihan dapat menurunkan penyerapan $\mathrm{Mg}$ dan $\mathrm{Ca}$ yang dibutuhkan dalam proses metabolisme tanaman, kekurangan $\mathrm{Mg}$ akan menghambat pembentukan klorofil sehingga fotosintesis akan terhambat, bila terjadi kekurangan $\mathrm{Ca}$ pada tanaman akan menyebabkan terbatasnya ukuran buah ( Rinsema, 1986:99).

Bahan organik yang belum matang ( $\mathrm{C} / \mathrm{N}$ tinggi) juga dianggap merugikan karena bila diberikan secara langsung ke dalam tanah maka bahan organik diserang oleh mikrobia bakteri maupun fungi untuk memperoleh energi. Sehingga populasi mikrobia 
Pengaruh Pupuk Kandang Kotoran Ayam Terhadap Pertumbuhan Dan Hasil Tomat (Lycopersicum esculentum. Mill)

yang tinggi memerlukan juga hara tanaman untuk tumbuhan dan kembang biak. Hara yang seharusnya digunakan oleh tanaman berubah digunakan oleh mikrobia, dengan kata lain mikrobia bersaing dengan tanaman untuk merebutkan hara yang ada hara menjadi tidak tersedia atau unavailable karena berubah dari senyawa anorganik menjadi senyawa organik jaringan mikrobia, hal ini disebut immobilisasi hara. Terjadinya immobilisasi hara tanaman bahkan sering menimbulkan adanya gejala defisiensi, makin banyak bahan organik yang diberikan kedalam tanah makin tinggi populasi yang menyerangnya, makin banyak hara yang mengalami immobilisasi. Walaupun demikian nantinya bila mikrobia mati akan mengalami dekomposisi hara yang immobil tersebut berubah menjadi tersedia lagi. Jadi immobilisasi merupakan pengikatan hara tersedia menjadi tidak tersedia dalam jangka waktu relatif tidak terlalu lama.

Menurut Hardjadi (1979:104), pembesaran sel-sel terjadi tepat berada di belakang titik tumbuh. Jika sel-sel pada pada daerah ini mulai membesar, vakuola-vakuola yang besar terbentuk. Vakuola ini secara relatif menghisap air dalam jumlah besar. Akibat dari absorpsi air, dinding-dinding sel bertambah tebal, karena menumpuknya selulosa tambahan yang terbuat dari gula. Jika laju pembelahan sel dan perpanjangannya serta pembentukan jaringan berjalan cepat, pertumbuhan akar tanaman juga akan berjalan cepat, karena pembelahan, pembesaran dan pembentukan jaringan memerlukan persediaan karbohidrat yang dipergunakan dalam proses-proses perkembangan akar tanaman. Ketersediaan karbohidrat ini sangat bergantung terhadap ketersediaan unsur hara dalam tanah, unsur hara tersebut berupa, N, P dan K. Nitrogen berfungsi untuk menaikan produksi tanaman, fosfor diperlukan untuk pembentukan primordia bunga dan organ tanaman untuk reproduksi, sedangkan kalium berfungsi dalam pengembangan sel dan pengatur tekanan osmosis. Selain itu kalium juga berfungsi dalam membentuk dan mengangkut karbohidrat. Sebagai katalisator pembentukan protein, mengatur berbagai kegiatan unsur mineral, menetralkan reaksi dalam sel terutama dari asam organik, menaikan pertumbuhan jaringan meristem. 


\section{KESIMPULAN DAN SARAN}

\section{Kesimpulan}

1. Pupuk kandang kotoran ayam berpengaruh nyata terhadap pertumbuhan dan hasil tanaman tomat berdasarkan hasil pengamatan terhadap tinggi tanaman, jumlah buah, dan berat buah.

2. Pemberian $2 \mathrm{~kg} / \mathrm{m}^{2}$ menghasilkan petumbuhan dan hasil tertinggi tanaman tomat dalam penelitian ini. Tinggi tanaman rata-rata $81,35 \mathrm{~cm}$, jumlah buah rata-rata 31,25 buah, dan berat buah rata-rata 1062,30 gram per tanaman.

\section{Saran}

Melalui hasil penelitian ini disarankan untuk:

1. Memberikan pupuk kandang kotoran ayam dalam meningkatkan pertumbuhan dan hasil tanaman tomat.

2. Pemberian pupuk kandang kotoran ayam $2 \mathrm{~kg} / \mathrm{m}^{2}$ cukup optimal meningkatkan pertumbuhan dan hasil tanaman tomat.

\section{DAFTAR PUSTAKA}

Bernadus. TW. 2002. Bertanam Tomat. Jakarta: Agromedia Pustaka.
Cahyono, B. 2008. Tomat. Yogyakarta: Kanisius.

Direktorat Jederal HortikulturA. 2014. http/www.hortikultura.pertanian. go.id.

Gasperz. 1994. Rancangan Percobaan Praktis Bidang Pertanian. Yogyakarta: Kanisius.

Hardjadi, SS. 1997. Pengantar Agronomi. Jakarta: Gramedia Pustaka.

Hakim, N., Y.N. Nyakpa., A.M. Lubis., G.N. Sutopo., M.R.Saul., M.A. Diha., Go Ban Hong, dan Bailey. Dasar Dasar Ilmu Tanah. Lampung: Universitas Lampung.

Hartatik, W., dan L.R. Widowati. 2009. Pupuk Kandang. Bogor: Badan Penelitian Tanah.

Hardjowigeno, S. 1993. Klasifikasi Tanah dan Pedogenesis. Jakarta: Akademika Pressindo.

Indrihastuti, D. 2004. Kandungan Kalsium pada Biomassa Tanaman Acacia Magium Willd dan pada Tanah Podsolik Merah Kuning di Hutan Tanaman Industri. Skripsi. Fakultas Kehutanan IPB.

Lingga, P. 2008. Petunjuk Penggunaan Pupuk. Jakarta: Penebar Swadaya.

Pracaya. 2003. Bertanam Tomat. Yogyakarta: Kanisius.

Prahasta, A. 2009. Budidaya Tomat. Jakarta: Penebar Swadaya. 
Pengaruh Pupuk Kandang Kotoran Ayam Terhadap Pertumbuhan Dan Hasil Tomat (Lycopersicum esculentum. Mill)

Rao, NS. 1994. Mikroorganisme Tanah dan Pertumbuhan Tanaman. Susilo H, Penerjemah. Jakarta (ID): UI Press.

Rinsema. 1986. Pupuk dan Cara Pemupukan. Bhratara Karya Aksara, Jakarta.

Rukmana, R. 1998. Budidaya tomat. Yogyakarta: Kanisius.

Salisbury, F. B., dan C. W. Ross. 1995. Fisiologi Tumbuhan III. Perkembangan Tumbuhan dan
Fisiologi Lingkungan.

Terjemahan D.R. Lukman dan Sumaryono. Penerbit ITB, Bandung.

Sutejo, M. M, 2002. Pupuk dan Cara Pemupukan. Penerbit Rineka Cipta, Jakarta.

Tugiyono, H. 2011. Bertanam Tomat. Jakarta: Penebar Swadaya.

Wiryanta, BT. 2002. Bertanam Tomat. Jakarta: Agromedia Pustaka. 